"European and global financial integration: some panel evidence of the convergence of interest rates"

\begin{tabular}{|c|c|c|}
\hline AUTHORS & Cândida Ferreira & \\
\hline ARTICLE INFO & $\begin{array}{l}\text { Cândida Ferreira (2016). Europ } \\
\text { evidence of the convergence of } \\
152-160 \text {. doi:10.21511/bbs.11(4 }\end{array}$ & $\begin{array}{l}\text { ks and Bank Systems, 11(4-1), } \\
\text { ks integration: some panel }\end{array}$ \\
\hline DOI & http://dx.doi.org/10.21511/bbs.1 & \\
\hline RELEASED ON & Thursday, 22 December 2016 & \\
\hline JOURNAL & "Banks and Bank Systems" & \\
\hline FOUNDER & LLC "Consulting Publishing Cor & Perspectives" \\
\hline & & $\begin{array}{l}\text { ニ } \\
\text { Z }\end{array}$ \\
\hline NUMBER OF REFERENCES & NUMBER OF FIGURES & NUMBER OF TABLES \\
\hline
\end{tabular}

C The author(s) 2022. This publication is an open access article. 


\title{
European and global financial integration: some panel evidence of the convergence of interest rates
}

\begin{abstract}
This paper seeks to contribute to the literature on financial integration using panel estimates to test beta- and sigmaconvergence across the European Union countries' interest rates and towards two specific benchmarks - the German and US rates - covering the time interval between 1999 and 2014 and taking into account the recent international financial crisis. The findings point to the existence of a process of convergence of interest rates and this process may be considered as part of the global process of integration. Furthermore, there is evidence of convergence to the chosen benchmarks, in particular of short-term real interest rates; the speed of this convergence towards the German rates clearly increased in the EU as a response to the financial crisis.
\end{abstract}

Keywords: financial integration, banking market, European interest rates, beta-convergence, sigma-convergence, panel data estimates.

JEL Classification: C2, E4, F3, G1, G2.

\section{Introduction}

Since the 1970s, and particularly after the collapse of the Bretton Woods system, followed by the first acute, deep oil crisis, there has been a global trend of reducing the barriers to free international trade and of establishing a clear process of international financial liberalization (Obstfeld, 1998; Rose and Van Wincoop, 2001; Baier and Bergstrand, 2007; De Nicolò and Juvenal, 2012).

Simultaneously, in Europe, a remarkable process of integration has taken place mostly with the aim of guaranteeing the stability and security of the continent. This process started with the common undertaking of six countries and has evolved into the European Union (EU), at present incorporating 28 member states. The establishment of the Economic and Monetary Union (EMU) in 1999 was supposed to accelerate the process of economic consolidation and financial integration both between the countries in the euro area and across the EU as a whole (Cabral et al., 2002; Hartman et al., 2003; Sørensen and Gutiérrez, 2006; Jappelli and Pagano, 2008, Arghyrou et al., 2009).

Under these conditions, the EU countries have been subject to different types of integration: an international form, following the general process of globalization, and the specific processes of European integration not only into the EU, but also into the EMU.

However, there is no clear consensus on evidence of the increasing consolidation and integration of European markets. Some empirical studies have even concluded that European financial markets are far from integrated (Centeno and Mello, 1999; Gardener et al., 2002; Affinito and Farabullini, 2009; Gropp and Ka-

\footnotetext{
(C) Cândida Ferreira, 2016.

Cândida Ferreira, Professor, ISEG, UL - Lisbon School of Economics and Management of the Universidade de Lisboa and UECE - Research Unit on Complexity and Economics, Portugal.

Financial support by FCT (Fundação para a Ciência e a Tecnologia), Portugal is gratefully acknowledged. This article is part of the Strategic Project (UID/ECO/00436/2013).
}

shyap, 2009). For different EMU members, Hartmann et al. (2003) found no support for the argument that financial integration leads to convergence in financial structures. Baele et al. (2004) considered five key euroarea markets (money, government bonds, corporate bonds, banking/credit, and equity markets) and concluded that these distinct market sectors have attained different levels of integration.

With regard to interest rates in the EU countries, several empirical studies, mainly using harmonized statistics such as the 'IMF interest rates' available since January 2003, have shown divergences in the level of interest rates across member states (Martin-Oliver et al., 2005; European Central Bank, 2007, 2008; Affinito and Farabullini, 2009).

Kleimeier and Sander (2000), using cointegration analysis, provided evidence of the degree of integration of the interest rates in six core EU countries, Japan, and the US for the 1985-1997 period, concluding that there was a convergence process, particularly with respect to spreads, but only at the regional level rather than as a global phenomenon. They also concluded that European lending rates were not yet fully integrated and noted that the segmentation of European financial markets posed an additional challenge to the implementation of a unified monetary policy.

Arghyrou et al. (2009) tested the convergence of real rates in the EU, using the EMU average as a benchmark. Following the methodology proposed, among others, by Ferreira and León-Ledesma (2007), they applied an augmented Dickey-Fuller test and, using monthly rates provided by DataStream for the 1996-2005 period, obtained empirical evidence of convergence.

To our knowledge, not many papers have addressed the controversial issue of financial integration across the EU member states, comparing it with global financial integration and taking into account the possible influence of the recent international crisis. 
This paper aims to contribute to the literature on financial integration, providing empirical evidence of the convergence of interest rates across the EU member states during the 1999-2014 period and comparing these results with the convergence of the interest rates of other developed European and non-European countries. By borrowing the concepts of beta- and sigmaconvergence from the economic growth literature and adopting panel estimates and the methodology proposed, among others, by Baele et al. (2004), we aim to answer to three specific questions:

- Is there a clear process of interest rate convergence across the EU countries and is it more evident than the global process of convergence across some relevant European and non-European developed countries?

- Is it possible to identify different patterns and speeds of approximation of EU and non-EU countries' rates towards the German and US interest rates?

- Did the recent international financial crisis provoke the same kind of reactions in interest rate convergence across EU and non-EU countries?

The remainder of this paper is structured as follows. The next section presents the data used and the adopted methodology. Section 2 reports the obtained empirical results and final section summarizes and concludes.

\section{Data and methodology}

1.1. Data. The use of the available AMECO series is a guarantee of the compatibility of all data. We select the series of nominal and real (using both the private consumption and GDP deflators) long-term and short-term interest rates and yield curves. These allow us to compare the evolution of the degree of integration between all current EU member states and some developed non-EU countries.

With these series, we calculate, for each of the selected countries, the differences between the country's rate and the two chosen benchmarks: Germany's rate and US's rate ${ }^{1}$. Thus, for all EU countries included in our panels, we consider the following variables:

1. ILN $=$ Nominal long-term interest rate

2. $\quad$ ILRC $=$ Real long-term interest rates, using the private consumption deflator

3. $\mathrm{ILRV}=$ Real long-term interest rates, using the GDP deflator

4. $\mathrm{ISN}=$ Nominal short-term interest rates

5. $\quad$ ISRC $=$ Real short-term interest rates, using the private consumption deflator

${ }^{1}$ Except for the individual series of these two countries, where in all situations, we must consider the differences in the other benchmark's rates. Thus, for Germany, we always take account of the difference between German rates and US rates, and vice versa.
6. ISRV $=$ Real short-term interest rates, using the GDP deflator

7. IYN $=$ Yield curve $(=\mathrm{ILN}-\mathrm{ISN})$

8. $\Delta \mathrm{ILN}_{\text {Germany }}=(\mathrm{ILN})_{i}-(\mathrm{ILN})_{\text {Germany }}$

9. $\Delta \mathrm{ILRC}_{\text {Germany }}=(\text { ILRC })_{i}-(\text { ILRC })_{\text {Germany }}$

10. $\Delta \mathrm{ILRV}_{\text {Germany }}=(\mathrm{ILRV})_{i}-(\mathrm{ILRV})_{\text {Germany }}$

11. $\Delta \mathrm{ISN}_{\text {Germany }}=(\mathrm{ISN})_{i}-(\mathrm{ISN})_{\text {Germany }}$

12. $\Delta \mathrm{ISRC}_{\text {Germany }}=(\mathrm{ISRC})_{i}-(\text { ISRC })_{\text {Germany }}$

13. $\Delta \mathrm{ISRV}_{\text {Germany }}=(\mathrm{ISRV})_{i}-(\mathrm{ISRV})_{\mathrm{Germany}}$

14. $\Delta \mathrm{IYN}_{\text {Germany }}=(\mathrm{IYN})_{i}-(\mathrm{IYN})_{\text {Germany }}$

15. $\Delta \mathrm{ILN}_{\mathrm{US}}=(\mathrm{ILN})_{i}-(\mathrm{ILN})_{\mathrm{US}}$

16. $\Delta \mathrm{ILRC}_{\mathrm{US}}=(\mathrm{ILRC})_{i}-(\mathrm{ILRC})_{\mathrm{US}}$

17. $\Delta \mathrm{ILRV}_{\mathrm{US}}=(\mathrm{ILRV})_{i}-(\mathrm{ILRV})_{\mathrm{US}}$

18. $\Delta \mathrm{ISN}_{\mathrm{US}}=(\mathrm{ISN})_{i}-(\mathrm{ISN})_{\mathrm{US}}$

19. $\Delta \mathrm{ISRC}_{\mathrm{US}}=(\mathrm{ISRC})_{i}-(\mathrm{ISRC})_{\mathrm{US}}$

20. $\Delta \mathrm{ISRV}_{\mathrm{US}}=(\mathrm{ISRV})_{i}-(\mathrm{ISRV})_{\mathrm{US}}$

21. $\Delta \mathrm{IYN}_{\mathrm{US}}=(\mathrm{IYN})_{i}-(\mathrm{IYN})_{\mathrm{US}}$

Using the available data, we consider the following panels of countries:

- Panel 1: including 35 developed countries, namely all currently EU member states and other European and non-European developed countries considered in the AMECO database (Iceland, Turkey, Norway, Switzerland, the United States, Japan, and Canada). Panel 1-A considers the years before the recent international financial crisis (1999-2008) and Panel 1$\mathrm{B}$ enlarges the time period, considering the 1999-2014 period.

- Panel 2: only including the 28 EU countries. Again, Panel 2-A is only for the years before the recent international financial crisis (1999-2008), while Panel 2-C is for the 1999-2014 period.

1.2. Beta-convergence estimations. In the economic growth literature, typical convergence studies consider the regression of the average per capita GDP growth rate of regions or countries with different income levels and the initial level of their income. There is convergence if the value of the regression coefficient (usually represented by $\beta$ ) is negative; this indicates that poor regions or countries are growing faster than rich ones, and, in turn, are becoming more homogeneous in their per capita incomes (see, among others, Barro and Sala-i-Martin, 1992; Mankiw et al., 1992; Sala-i-Martin, 1996).

Beta-convergence models have been borrowed from the literature on economic growth and adapted to measure the progress of financial integration, among others by Adam et al. (2002), Baele et al. (2004), and the European Central Bank $(2007,2008)$.

Using panel data, here we also borrow from this literature and opt to estimate the following equation:

$\left(r_{i, t}-r_{i, t-1}\right)=\alpha+\beta r_{i, t-1}+\gamma\left(r_{i, t-1}-r_{i, t-2}\right)+\varepsilon_{i, t}$, 
where $r$ represents interest rate, $i$ and $t$ denote the country and time indices, respectively, $\alpha$ is the independent term, and $\varepsilon_{i, t}$ is the error term, denoting the exogenous shocks that force the interest rate differentials between the considered countries.

The presence of negative betas signals convergence to the averages of the series, and the magnitude of the betas denotes the speed of this convergence.

1.3. Sigma-convergence estimations. From economic growth literature, we can also borrow the widely used concept of sigma-convergence, which typically measures the dispersion of the per capita income across a group of regions or countries. Sala-i-Martin (1994, 1996) defends beta-convergence as a more interesting measure of convergence and demonstrates that betaconvergence is a necessary, but not a sufficient condition for sigma-convergence. Nevertheless, beta- and sigma-convergence are usually considered as complementary measures and are used together in many empirical convergence studies. The main idea behind sigma-convergence is that all regions or countries converge to the same level of economic output and sigmaconvergence can be defined as the lowering of variance of real GDP per capita among these regions or countries, representing the catching-up effect during the considered time period.

As in growth studies, financial integration literature considers that sigma-convergence occurs when the cross-sectional standard deviation of a variable, such as an interest rate, is decreasing over time (see, for instance, Adam et al., 2002; Baele et al., 2004; Casu and Girardone, 2009).

In this paper, we want to test the convergence of the interest rate series to the chosen benchmarks (either German or US interest rates) to estimate the following model:

$$
\Delta r_{i, t}-\Delta r_{i, t-1}=\eta+\sigma \Delta r_{i, t-1}+v_{i, t}
$$

where $\Delta r_{i, t}$ represents the difference between the country's $i$ interest rate and the correspondent benchmark's rate at moment $t, \Delta r_{i, t-1}$ denotes the difference between the country's $i$ interest rate and the correspondent benchmark's rate at the moment $t$ $1, \eta$ is the independent term, and $v_{i, t}$ is the error term.

The value of the sigma is supposed to be negative and represents the rate of convergence towards the correspondent benchmark; so, the larger the absolute value of sigma is, the faster the cross-sectional convergence to the chosen benchmark (either the German or the US rates) will be.

1.4. Testing cointegration. Here cointegration is tested with the implementation of the four panel tests developed by Westerlund (2007) and Westerlund and Edgerton (2007), which test for the absence of cointegration by determining whether individual panel members are error correcting. These tests are flexible, work well in unbalanced, heterogeneous, and/or relatively small panels and allow for dependence both between and within cross-panel units.

The application of these panel cointegration tests to the $i$ series included in one panel considers, for each moment $t$ (during the time interval $t=0, \ldots, p$ ), the following errorcorrection model: $D r_{i t}=c_{i}+a_{i l} * D r_{i t-1}+$ $+\ldots+a_{i p} * D r_{i t-p}+b_{i 0} * D x_{i t}+b_{i 1} * x_{i t-1}+\ldots+b_{i p} * D x_{i t-p}+$ $+a_{i}\left(r_{i t-1}-b_{i} * x_{i t-1}\right)+u_{i t}$.

These Westerlund cointegration tests provide four test statistics: $G t, G a, P t$, and $P a$.

The $G t$ and $G a$ statistics test $H 0: a_{i}=0$ for all $i$ versus $H 1: a_{i}<0$ for at least one of the series, $i$, starting from a weighted average of the individually estimated coefficients $a_{i}$ and their respective $t$-ratios.

The $P t$ and $P a$ test statistics consider the pooled information of all panel cross-section units to test HO: $a_{i}=0$ for all $i$ versus H1: $a_{i}<0$ for all crosssection units. Thus, the rejection of $H O$ must always be taken as the rejection of cointegration for the whole panel. Any single cross-unit can cause the rejection of $\mathrm{HO}$ and it is not possible to identify which cross-unit is responsible for this rejection.

\section{Empirical results}

In this section, we present the results obtained for the defined panels.

For Panel 1, which includes the 35 developed countries, we consider first Panel 1-A with 350 observations for the years before the recent crisis, 19992008, and second Panel 1-B with 560 observations for the entire 1999-2014 period.

For Panel 2, where we include only the $28 \mathrm{EU}$ member states, we also have Panel 2-A, with 280 observations, for the 1999-2008 period, and Panel 2-B with 448 observations for the 1999-2014 period.

Here, we report first the results obtained for the beta-convergence estimations with equation(1), then those obtained for the sigma-convergence estimations with equation (2), and, finally, we complement our analysis with the results obtained with the Westerlund cointegration test.

2.1. Results obtained with the beta-convergence estimations. Table 1 provides the results obtained for beta-convergence with the estimation of equation (1) using panel fixed effects estimates, which Hausman tests revealed to be more adequate than random effects estimates ${ }^{1}$. Panel fixed effects estimations assume that the individual country-specific effects are random

${ }^{1}$ The results obtained with panel random effects estimates and the Hausman tests are not presented in this paper, but can be provided on request. 
variables that are allowed to be correlated with the explanatory variables; these estimates are clearly adequate when we are only interested in analyzing the impact of variables that vary over time, as with the considered series of interest rates.

\section{(Table 1 Around here)}

From the results reported in Table 1, we can see that the statistical significance of the results for the coefficients and the independent term are, in general, acceptable, especially for the beta coefficients. Moreover, in all situations, the betas are negative and statistically very significant, indicating the clear presence of convergence in the considered interest rate series across the countries included in the panels.

The comparison of the results obtained for the two panels of countries allows us to conclude that not only beta-convergence is a reality among the EU member states' interest rates included in Panel 2, but also, and sometimes even with a higher speed of convergence, among the interest rates of these countries and the other developed countries included in Panel 1.

The results obtained for the long-term and the shortterm series reveal that, in general, and in both panels of countries, the magnitude of the betas is higher in the short term than in the long term. This tendency is also confirmed by the statistically significant yet not very strong speed of convergence of the 'yield curve', which, according to the definition of the AMECO database, is the difference between the nominal longterm and the nominal short-term interest rate series.

In addition, for both panels, the comparison of the results obtained for the time period before the recent financial crisis (1999-2008) and those including the years of the crisis (1999-2014) clearly show the relevance of this financial crisis for the interest rates series' convergence in the considered panels of countries. With the exception of the results obtained for the nominal short-term interest rate series, particularly for Panel 1, all the other results reveal higher betas in the panels including the years of the crisis (Panel 1-B and Panel 2-B).

These results allow us to conclude that, in general, for the universe of the considered EU and non-EU developed countries, in spite of the recognized heterogeneities and different individual consequences of the crisis for each country, after 2008, there was a remarkable increase in the speed of convergence of the countries' interest rate series.

2.2. Results obtained with the sigma-convergence estimations. In Table 2, we present the results obtained with the estimation of equation (2), which tests the sigma-convergence, that is, the crosssection dispersion and the possible convergence of the interest rate series to the chosen benchmarks (here either the German or the US rates). We go on following the indications of the Hausman test, which recommends the results obtained with panel fixed effects estimations, assuming that the individual country-specific effect is correlated with the independent variable.

\section{(Table 2 Around here)}

The results provided in Table 2 reveal that there is clear cross-sectional convergence towards the benchmarks, as the obtained sigma coefficients are always negative and statistically very significant.

With regard to the speed of convergence to the benchmarks (the absolute values of the sigma), they have similar patterns in both panels, but, in general, they are slightly higher in Panel 1 than in Panel 2, revealing that there is evidence of convergence to the considered benchmarks not only among all the EU member states, but also, and with more intensity, among these and the other developed countries included in Panel 1.

In all situations, and in line with the previous results obtained with the beta-convergence estimations, the speed of the sigma-convergence is always higher for the short-term than for the longterm interest rate series.

In both panels, the real interest rate series (both using the private consumption and the GDP deflators) almost always converge faster to the benchmarks than the nominal rates, and this is true both for the long-term and the short-term rates.

Moreover, for the long-term interest rates in the two panels and for the short-term interest rates in Panel 1 only, the speeds of convergence towards the benchmarks are higher during the years before the recent crisis (Panel 1-A for the 1999-2008 period) than when we also include the years of the crisis (Panel 1-B for the 1999-2014 period).

The results obtained for the short-term interest rates in Panel 2, which only includes the 28 EU member states, reveal, on the one hand, that the nominal rate (which is often considered to be a proxy for the monetary policy rate) continues converging at similar speeds before and after the crisis, while, on the other hand, the real interest rates series, both considering the private consumption and the GDP deflators, clearly show in Panel 2-B the increasing convergence of the EU real short-term interest rates, particularly to the German rates, reflecting the efforts of the EU economies to overcome the problems provoked by the financial crisis.

In what concerns specifically to the convergence towards the two benchmarks, there are clear differences in the speeds of adjustment across interest rate series and time periods. 
For the years before the crisis (1999-2008), there is clear evidence that in both panels, almost all interest rate series converge with a higher speed of adjustment towards the German rates; the exception is the nominal short-term interest rate, which slightly converges more towards the US rate.

The situation changes after the crisis, as for the time period including the years of the crisis (1999-2014), and again in both panels, only the real short-term rates (both considering the private consumption and the GDP deflators) continue to converge towards the German rates with higher speed than towards the US rates. However, for the real long-term rates the speed of adjustment is clearly higher towards the US rates.

2.3. Results obtained with the Westerlund cointegration test. In order to complement our previous analysis, we present in Table 3 the $p$-values obtained with the Westerlund cointegration test for each of the considered panels of countries and time periods (the values of the statistics and the $Z$-values are also available and will be provided on request).

\section{(Table 3 Around here)}

The cointegration results presented in Table 3 reveal that there are no main differences across the considered panels of countries. In all situations, the results obtained for the considered universe of 35 developed countries in Panel 1 are in line with the results of Panel 2, where we included only the EU member states.

According to these results, the cointegration of the individual countries' rates and the German rates cannot be rejected for the majority of the series. The exceptions are to be found mostly for the nominal long-term rates, but only for the time period including the years of the crisis (1999-2014), and also for the yield rates (which represent the difference between the long-term and the short-term nominal rates), but only for the years before the crisis (1999-2014).

In what concerns the cointegration with the US rates, the results for the yield rates are completely in line with those obtained for the cointegration with the German rates. In both panels of countries, cointegration cannot be rejected for all considered shortterm rates, but this is not so clear for the long-term rates. A more detailed observation of the results obtained for the long-term rates allows us to conclude that in almost all situations cointegration can clearly be rejected for the nominal rates and for the real rates using the private consumption deflator, but only before the financial crisis (the 1999-2008 period). In addition, for the other long-term real series cointegration cannot be completely rejected, particularly taking into account the results of the $\mathrm{Pt}$ and $\mathrm{Pa}$ statistics, which consider the pooled information of all panel cross-section units (here, the included developed EU and non-EU countries).

\section{Summary and conclusions}

This paper contributes to the literature by using panel data estimations to test beta- and sigma-convergence and also cointegration across the EU countries' interest rates and the speeds of their convergence towards two specific benchmarks: German and US interest rates.

The data are sourced from AMECO and include the available series of both nominal and real long-term and short-term interest rates covering the 1961-2008 period. The analysis considers two panels of EU countries: one including all the countries for which AMECO provides the used interest rate series and another with all the current EU member states. In both situations, the possible influences of the recent global financial and European debt crisis are taken into account.

The empirical findings allow us to conclude that:

1. There is a clear process of European integration, namely in what concerns the convergence of interest rates, which may be considered as part of the global process of integration. More precisely, there is clear evidence of beta-convergence not only among the interest rates of the $28 \mathrm{EU}$ member states, but also among the interest rates of the EU and non-EU developed countries that we considered in our analysis.

This conclusion is reinforced by the cointegration test results, as in all reported situations, the values obtained for Panel 1 with 35 developed countries are completely in line with those obtained for Panel 2, where we include only the $28 \mathrm{EU}$ countries.

2. It is possible to identify different speeds of convergence towards the benchmark rates of different series of interest rates in the two panels of countries. In general, in both panels, the sigmaconvergence is higher for the short-term than for the long-term interest rates. However, it is not evident that the interest rates of the EU countries always converge more to Germany's or to the US's rates. In addition, the cointegration tests do not reveal clear differences in the possible existence of cointegration between each of the interest rate series and the two considered benchmarks (the German and the US rates).

Considering the years before the recent international financial crisis (1999-2008), the results reveal that in our two panels of developed countries (the first with EU and non-EU countries and the second with only the 28 EU memberstates), almost all interest rate series converge with a higher speed of adjustment towards Germany's rates, with the exception of the nominal short-term interest rate, which slightly converges more towards the US's rates. 
On the other hand, when we include the years after the crisis, that is, considering the 1999-2014 period, and again in both panels of countries, only the real short-term rates continue to converge towards Germany' rates with a higher speed than towards the US' rates. However, with regard to the real long-term rates, the speed of adjustment is clearly stronger towards the US's rates.

3. Furthermore, the results obtained not only allow us to conclude about the importance of the recent international crisis for the interest rates' convergence, but also reveal that the speed of this convergence clearly increased after the crisis not only in the EU, but also in the other non-EU developed countries included in our analysis.

Further research is needed to analyze the complex process of financial integration and to clarify the factors that affect economic agents, both on the supply and on the demand sides of financial markets. This is particularly relevant at a time when the world is still undergoing a deep economic and financial crisis that has affected market structures and showed the heterogeneity across EU and non-EU countries with remarkable differences in their robustness in dealing with financial turbulence.

\section{References}

1. Adam, K., Jappelli, T., Menichini, A.M., Padula, M. and Pagano, M. (2002). Analyse, Compare, and Apply Alternative Indicators and Monitoring Methodologies to Measure the Evolution of Capital Market Integration in the European Union, Centre for Studies in Economics and Finance (CSEF), University of Salerno.

2. Affinito, M. and Farabullini, F. (2009). Does the law of one price hold in euro-area retail banking?An empirical analysis of interest rate differentials across the monetary union, International Journal of Central Banking, Vol. 5 (1), pp. 5-37.

3. Arghyrou, M.G., Gregoriou, A., and Kontonikas, A. (2009). Do real interest rates converge? Evidence from the European union, Journal of International Financial Markets, Institutions \& Money, Vol. 19 (3), pp. 447-460.

4. Baele, L., Ferrando, A., Hördahl, P., Krylova, E. and Monnet, C. (2004). Measuring European financial integration, Oxford Review of Economic Policy, Vol. 20 (4), pp. 509-530.

5. Baier, S.L. and Bergstrand, J.H. (2007). Do free trade agreements currently increase members' international trade? Journal of International Economics, Vol. 71 (1), pp. 72-95.

6. Barro, R.J. and Sala-i-Martin, X. (1992). Convergence, Journal of Political Economy, Vol. 100 (2), pp. 223-251.

7. Cabral I., Dierick, F. and Vesala, J. (2002). Banking Integration in the Euro Area, ECB Occasional Paper Series No. 6.

8. Casu, B. and Girardone, C. (2009). Integration and efficiency in EU banking markets, in M. Balling, E.Gnan, F.Lierman, and J.-P.Schoder (Eds.), Productivity in the Financial Services Sector, pp. 89-110. SUERF.

9. Centeno, M. and Mello, A.S. (1999). How integrated are the money market and bank loans market within the European Union? Journal of International Money and Finance, Vol. 18 (1), pp. 75-106.

10. De Nicolò, G. and Juvenal, L. (2012). Financial Integration, Globalization, and Real Activity, CESifo Working Paper No. 3737.

11. European Central Bank. (2007). Financial Integration in Europe.

12. European Central Bank. (2008). Financial Integration in Europe.

13. Ferreira, A.L. and León-Ledesma, M.A. (2007). Does the real interest parity hypothesis hold? Evidence from developed and emerging markets, Journal of International Money and Finance, Vol. 26 (3), pp. 364-382.

14. Gardener, E.P.M., Molyneux, P. and Moore, B. (Eds.). (2002). Banking in the New Europe - The Impact of the Single Market Programme and EMU on the European Banking Sector. Palgrave Macmillan.

15. Gropp, R. and A. Kashyap. (2009). A New Metric for Banking Integration in Europe, NBER Working Paper No. 14735.

16. Hartmann P., Maddaloni, A. and Manganelli, S. (2003). The euro-area financial system: Structure, integration, and policy initiatives, Oxford Review of Economic Policy, Vol. 19 (1), pp. 180-213.

17. Jappelli, T. and M. Pagano. (2008). Financial Market Integration under EMU, CSER Working Paper No. 197.

18. Kleimeier, S. and Sander, H. (2000). Regionalisation versus globalisation in European financial market integration: Evidence from co-integration analysis, Journal of Banking \& Finance, Vol. 24 (6), pp. 1005-1043.

19. Mankiw, N.G., Romer, D. and Weil, D.N. (1992). A contribution to the empirics of economic growth, The Quarterly Journal of Economics, Vol. 107 (2), pp. 407-437.

20. Martin-Oliver, A., Salas-Fumás, V. and Saurina, J. (2005). A Test of the Law of One Price in Retail Banking, Banco de EspañaWorking Paper, No. 0530.

21. Obstfeld, M. (1998). The global capital market: Benefactor or menace? The Journal of Economic Perspectives, Vol. 12 (4), pp. 9-30.

22. Rose, A.K., and E. van Wincoop. (2001). National money as a barrier to international trade: The real case for currency union, American Economic Review, Vol. 91 (2), pp. 386-390.

23. Sala-i-Martin, X. (1994). Cross-sectional regressions and the empirics of economic growth, European Economic Review, Vol. 38 (3-4), pp.739-747.

24. Sala-i-Martin, X.X. (1996). Regional cohesion: Evidence and theories of regional growth and convergence, European Economic Review, Vol. 40 (6), pp. 1325-1352.

25. Sørensen, C.K. and Gutiérrez, J.M.P. (2006). Euro Area Banking Sector Integration: Using Hierarchical Cluster Analysis Techniques, ECB Working Paper No. 627.

26. Westerlund, J. (2007). Testing for error correction in panel data, Oxford Bulletin of Economics and Statistics, Vol. 69 (6), pp. 709-748.

27. Westerlund, J. and Edgerton, D.L. (2007). A panel bootstrap cointegration test, Economics Letters, Vol. 97 (3), pp. 185-190. 


\section{Appendix}

Table 1. Beta convergence results

PANEL 1- 35 developed countries (1) PANEL 2 - 28 EU countries.

\begin{tabular}{|c|c|c|c|c|c|c|c|c|c|c|c|c|}
\hline \multirow[t]{2}{*}{ Variables (2) } & \multicolumn{3}{|c|}{ P1-A: 1999-2008 } & \multicolumn{3}{|c|}{ P1-B: 1999-2014 } & \multicolumn{3}{|c|}{ P2-A: 1999-2008 } & \multicolumn{3}{|c|}{ P2-B: 1999-2014 } \\
\hline & $\alpha$ & & $\beta \gamma$ & $\alpha$ & & $\beta \gamma$ & $\alpha$ & & $\beta \gamma$ & $\alpha$ & & $\beta \gamma$ \\
\hline \multicolumn{13}{|l|}{ Dep. Var.: ILN } \\
\hline Coef. & 2.0058 & -0.3868 & 0.0517 & 1.9011 & -0.4052 & 0.1874 & 2.1134 & -0.4232 & 0.1617 & 2.0088 & -0.4352 & 0.2168 \\
\hline Z-stat. & 7.71 & -8.14 & 1.45 & 9.42 & -10.58 & 5.18 & 8.03 & -8.56 & 3.45 & 8.70 & -9.99 & 5.23 \\
\hline$P>|z|$ & 0.000 & 0.000 & 0.149 & 0.000 & 0.000 & 0.000 & 0.000 & 0.000 & 0.001 & 0.000 & 0.000 & 0.000 \\
\hline \multicolumn{13}{|l|}{ Dep. Var.: ILRC } \\
\hline Coef. & 0.5508 & -0.3512 & -0.1087 & 1.2587 & -0.5502 & 0.0531 & 0.3870 & -0.3215 & -0.0772 & 1.2500 & -0.5567 & 0.0714 \\
\hline t-stat. & 3.17 & -5.30 & -2.07 & 8.65 & -11.73 & 1.21 & 2.30 & -4.68 & -1.33 & 7.69 & -10.69 & 1.45 \\
\hline$P>|t|$ & 0.002 & 0.000 & 0.039 & 0.000 & 0.000 & 0.227 & 0.023 & 0.000 & 0.185 & 0.000 & 0.000 & 0.147 \\
\hline \multicolumn{13}{|l|}{ Dep. Var.: ILRV } \\
\hline Coef. & 0.6993 & -0.2824 & -0.2953 & 1.2244 & -0.5861 & 0.0922 & 0.3649 & -0.3454 & 0.0173 & 1.1597 & -0.5614 & 0.1617 \\
\hline t-stat. & 3.96 & -7.54 & -10.21 & 7.95 & -12.33 & 2.09 & 2.58 & -5.71 & 0.22 & 7.05 & -11.30 & 3.32 \\
\hline$P>t \mid$ & 0.000 & 0.000 & 0.000 & 0.000 & 0.000 & 0.037 & 0.010 & 0.000 & 0.783 & 0.000 & 0.000 & 0.001 \\
\hline \multicolumn{13}{|l|}{ Dep. Var.: ISN } \\
\hline Coef. & 1.1344 & -0.7611 & -0.2045 & 0.6009 & -0.2609 & -0.2667 & 1.4986 & -0.3564 & -0.0421 & 0.7477 & -0.3162 & -0.0336 \\
\hline t-stat. & 6.03 & -10.68 & -4.48 & 3.60 & -10.88 & -12.71 & 10.15 & -15.86 & -2.22 & 6.86 & -16.27 & -1.88 \\
\hline$P>t \mid$ & 0.000 & 0.000 & 0.000 & 0.000 & 0.000 & 0.000 & 0.000 & 0.000 & 0.027 & 0.000 & 0.000 & 0.061 \\
\hline \multicolumn{13}{|l|}{ Dep.Var.: ISRC } \\
\hline Coef. & 0.3700 & -0.1937 & -0.1341 & 0.5858 & -0.6715 & -0.1569 & 0.4636 & -0.5171 & -0.1341 & 0.3472 & -0.6080 & 0.0284 \\
\hline t-stat. & 3.35 & -6.05 & -2.93 & 4.82 & -13.57 & -4.29 & 3.83 & -10.09 & -1.15 & 3.33 & -13.26 & 0.72 \\
\hline$P>t \mid$ & 0.001 & 0.000 & 0.003 & 0.000 & 0.000 & 0.000 & 0.000 & 0.000 & 0.251 & 0.001 & 0.000 & 0.470 \\
\hline \multicolumn{13}{|l|}{ Dep. Var.: ISRV } \\
\hline Coef. & 0.7217 & -0.6829 & -0.6829 & 0.5784 & -0.7695 & -0.0373 & 0.2760 & -0.4744 & -0.0975 & 0.3564 & -0.7118 & 0.0878 \\
\hline t-stat. & 4.10 & -10.45 & -10.45 & 4.39 & -14.88 & -0.97 & 2.14 & -9.15 & -2.05 & 2.88 & -13.94 & 2.07 \\
\hline$P>|t|$ & 0.000 & 0.000 & 0.000 & 0.000 & 0.000 & 0.334 & 0.034 & 0.000 & 0.041 & 0.004 & 0.000 & 0.039 \\
\hline \multicolumn{13}{|l|}{ Dep. Var.: IYN } \\
\hline Coef. & 0.1563 & -0.3645 & 0.1945 & 0.6003 & -0.3878 & 0.1904 & 0.2057 & -0.3827 & 0.1777 & 0.6765 & -0.3843 & 0.2014 \\
\hline t-stat. & 2.59 & -6.98 & 4.20 & 8.16 & -11.26 & 4.68 & 3.13 & -7.00 & 3.78 & 7.69 & -10.16 & 4.46 \\
\hline$P>t \mid$ & 0.010 & 0.000 & 0.000 & 0.000 & 0.000 & 0.000 & 0.02 & 0.000 & 0.000 & 0.000 & 0.000 & 0.000 \\
\hline
\end{tabular}

(1) This sample of 35 developed countries include all current 28 EU member states and also Iceland, Turkey, Norway, Switzerland, US, Japan and Canada.

(2) ILN = Nominal long-term interest rates; ILRC = Real long-term interest rates, deflator private consumption; ILRV = Real longterm interest rates, deflator GDP;

ISN $=$ Nominal short-term interest rates; ISRC $=$ Real short-term interest rates, deflator private consumption; ISRV $=$ Real shortterm interest rates, deflator GDP;

IYN $=$ Yield curve $(=$ ILN - ISN $)$. 
Table 2. Sigma convergence results

PANEL 1- 35 developed countries (1) PANEL 2 - 28 EU countries.

\begin{tabular}{|c|c|c|c|c|c|c|c|c|c|c|c|c|c|c|c|c|}
\hline \multirow[t]{3}{*}{ Variables (2) } & \multicolumn{4}{|c|}{ P1-A: 1999-2008 } & \multicolumn{4}{|c|}{ P1-B: 1999-2014 } & \multicolumn{4}{|c|}{ P2-A: 1999-2008 } & \multicolumn{4}{|c|}{ P2-B: 1999-2014 } \\
\hline & \multicolumn{4}{|c|}{$\Delta_{\text {Germany }} \Delta_{\mathrm{US}}$} & \multicolumn{4}{|c|}{$\Delta_{\text {Germany }} \Delta_{\text {US }}$} & \multicolumn{4}{|c|}{$\Delta_{\text {Germany }} \Delta_{\text {US }}$} & \multicolumn{4}{|c|}{$\Delta_{\text {Germany }} \Delta_{\mathrm{US}}$} \\
\hline & 1 & $\mu$ & $\rho \mu$ & $\rho$ & $\mu$ & & $\rho \mu$ & $\rho$ & & $\mu$ & $\rho \mu$ & $\rho$ & $\mu$ & & $\rho \mu$ & $\rho$ \\
\hline \multicolumn{17}{|l|}{ Dep. Var.: ILN } \\
\hline Coef. & 0.4943 & -0.4801 & 0.4756 & -0.4685 & 0.5540 & -0.3379 & 0.4894 & -0.3690 & 0.4197 & -0.5107 & 0.3286 & -0.4984 & 0.5230 & -0.3422 & 20.4102 & -0.3692 \\
\hline z-stat. & 7.40 & -9.44 & -6.07 & -8.34 & 7.28 & -9.96 & 6.56 & -10.64 & 6.68 & -9.70 & 5.50 & -8.29 & 6.12 & -9.06 & 5.02 & -9.51 \\
\hline$P>|z|$ & 0.034 & 0.000 & 0.000 & 0.000 & 0.000 & 0.000 & 0.000 & 0.000 & 0.000 & 0.000 & 0.000 & 0.000 & 0.000 & 0.000 & 0.000 & 0.000 \\
\hline \multicolumn{17}{|c|}{ Dep. Var.: ILRC } \\
\hline Coef. & -0.4790 & -0.6148 & 0.0073 & -0.5375 & 0.2255 & -0.3877 & 0.3145 & -0.4131 & -0.5792 & -0.5490 & -0.1303 & -0.4930 & 0.2143 & -0.3636 & 0.2772 & -0.3887 \\
\hline t-stat. & -5.13 & -9.92 & 0.09 & -9.22 & 2.45 & -10.52 & 3.64 & -11.32 & -5.23 & -8.35 & -1.43 & -7.90 & 1.99 & -9.03 & 2.78 & -9.74 \\
\hline$P>|t|$ & 0.000 & 0.000 & 0.924 & 0.000 & 0.014 & 0.000 & 0.000 & 0.000 & 0.000 & 0.000 & 0.153 & 0.000 & 0.047 & 0.000 & 0.006 & 0.000 \\
\hline \multicolumn{17}{|c|}{ Dep. Var.: ILRV } \\
\hline Coef. & -1.0578 & -0.6115 & -0.2229 & -0.5340 & 0.0857 & -0.4571 & 0.2835 & -0.4950 & -0.9153 & -0.4658 & -0.2456 & -0.4127 & 0.1109 & -0.3911 & 10.2500 & -0.4369 \\
\hline t-stat. & -7.21 & -10.55 & -2.08 & -9.67 & 0.65 & -11.71 & 2.47 & -12.77 & -5.90 & -7.83 & -2.20 & -7.26 & 0.76 & -9.45 & 1.95 & -10.55 \\
\hline$P>|t|$ & 0.000 & 0.000 & 0.039 & 0.000 & 0.513 & 0.000 & 0.014 & 0.000 & 0.000 & 0.000 & 0.029 & 0.000 & 0.445 & 0.000 & 0.052 & 0.000 \\
\hline \multicolumn{17}{|c|}{ Dep. Var.: ISN } \\
\hline Coef. & 0.8763 & -0.5434 & 1.0677 & -0.5496 & 0.6264 & -0.4823 & 0.7643 & -0.4859 & 0.2818 & -0.4047 & 0.5087 & -0.4169 & 0.2780 & -0.4012 & 20.3994 & -0.4058 \\
\hline t-stat. & 3.72 & -16.07 & 4.23 & -14.94 & 4.40 & -21.10 & 4.92 & -19.51 & 3.30 & -23.87 & 3.89 & -15.61 & 4.23 & -27.01 & 4.51 & -20.20 \\
\hline$P>|t|$ & 0.000 & 0.000 & 0.000 & 0.000 & 0.000 & 0.000 & 0.000 & 0.000 & 0.001 & 0.000 & 0.000 & 0.000 & 0.000 & 0.000 & 0.000 & 0.000 \\
\hline \multicolumn{17}{|c|}{ Dep. Var.: ISRC } \\
\hline Coef. & -0.3497 & -1.0876 & 0.4444 & -0.9886 & 0.0356 & -0.9492 & 0.6299 & -0.8720 & -0.5919 & -0.6276 & 0.0794 & -0.6059 & -0.1789 & -0.6952 & 20.3056 & -0.6308 \\
\hline t-stat. & -2.65 & -21.76 & 2.92 & -18.65 & 0.35 & -24.36 & 5.66 & -21.87 & -5.94 & -13.22 & 0.66 & -11.56 & -1.90 & -16.88 & 3.08 & -15.22 \\
\hline$P>|t|$ & 0.008 & 0.000 & 0.004 & 0.000 & 0.726 & 0.000 & 0.000 & 0.000 & 0.000 & 0.000 & 0.508 & 0.000 & 0.058 & 0.000 & 0.002 & 0.000 \\
\hline \multicolumn{17}{|c|}{ Dep. Var.: ISRV } \\
\hline Coef. & -1.1959 & -0.9512 & 0.0954 & -0.8571 & -0.2977 & -0.8916 & 0.4892 & -0.8246 & -1.1189 & -0.6411 & -0.0887 & -0.5933 & -0.4032 & -0.7253 & $\begin{array}{ll}3 & 0.2737 \\
\end{array}$ & -0.6749 \\
\hline t-stat. & -7.62 & -18.80 & 0.58 & -16.29 & \begin{tabular}{|l|}
-2.27 \\
\end{tabular} & -21.67 & 3.84 & -20.30 & -8.45 & -13.43 & -0.65 & -11.49 & -3.01 & -16.18 & 2.19 & -15.42 \\
\hline$P>|t|$ & 0.000 & 0.000 & 0.561 & 0.000 & 0.023 & 0.000 & 0.000 & 0.000 & 0.000 & 0.000 & 0.516 & 0.000 & 0.003 & 0.000 & 0.029 & 0.000 \\
\hline \multicolumn{17}{|c|}{ Dep. Var:. IYN } \\
\hline Coef. & 0.0090 & -0.3269 & -0.2478 & -0.4271 & 0.1898 & -0.3053 & -0.0412 & -0.2776 & 0.0291 & -0.3636 & -0.2291 & -0.4467 & 0.2511 & -0.2971 & 10.0133 & -0.3929 \\
\hline t-stat. & 0.19 & -7.09 & -3.53 & -8.60 & 3.54 & -10.03 & -0.64 & -9.51 & 0.63 & -7.74 & -3.10 & -8.27 & 3.98 & -8.90 & 0.18 & -10.23 \\
\hline$P>|t|$ & 0.849 & 0.000 & 0.128 & 0.000 & 0.000 & 0.000 & 0.521 & 0.000 & 0.526 & 0.000 & 0.002 & 0.000 & 0.000 & 0.000 & 0.855 & 0.000 \\
\hline
\end{tabular}

(1) This sample of 35 developed countries include all current 28 EU member states and also Iceland, Turkey, Norway, Switzerland, US, Japan and Canada.

(2) $\quad$ ILN = Nominal long-term interest rates; ILRC $=$ Real long-term interest rates, deflator private consumption; ILRV $=$ Real longterm interest rates, deflator GDP;

ISN $=$ Nominal short-term interest rates; ISRC $=$ Real short-term interest rates, deflator private consumption; ISRV $=$ Real shortterm interest rates, deflator GDP;

IYN = Yield curve (= ILN - ISN). 
Table 3. Westerlund panel cointegration test (p-values)

PANEL 1- 35 developed countries (1) PANEL 2 - 28 EU countries.

\begin{tabular}{|c|c|c|c|c|c|c|c|c|c|c|c|c|c|c|c|c|}
\hline \multirow{2}{*}{$\begin{array}{c}\text { Cointegration } \\
\text { between the variables }(2)\end{array}$} & \multicolumn{4}{|c|}{ P1-A: 1999-2008 } & \multicolumn{4}{|c|}{ P1-B: 1999-2014 } & \multicolumn{4}{|c|}{ P2-A: 1999-2008 } & \multicolumn{4}{|c|}{ P2-B: 1999-2014 } \\
\hline & Gt & $\mathrm{Ga}$ & $\mathrm{Pt}$ & $\mathrm{Pa}$ & Gt & $\mathrm{Ga}$ & $\mathrm{Pt}$ & $\mathrm{Pa}$ & Gt & $\mathrm{Ga}$ & $\mathrm{Pt}$ & $\mathrm{Pa}$ & $\mathrm{Gt}$ & $\mathrm{Ga}$ & $\mathrm{Pt}$ & $\mathrm{Pa}$ \\
\hline $\mathrm{ILN}$ and $\Delta \mathrm{IL} \mathrm{N}_{\text {Germany }}$ & 0.000 & 0.000 & 0.246 & 0.000 & 1.000 & 1.000 & 1.000 & 1.000 & 0.000 & 0.000 & 0.132 & 0.000 & 1.000 & 1.000 & 1.000 & 1.000 \\
\hline ILRCand $\Delta \mathrm{LLRC}$ Germany & 0.000 & 0.992 & 0.000 & 0.090 & 0.000 & 0.561 & 0.000 & 0.218 & 0.000 & 0.987 & 0.000 & 0.109 & 0.000 & 0.459 & 0.000 & 0.185 \\
\hline ILRVand $\Delta \mathrm{LLRV} V_{\text {Germany }}$ & 0.000 & 0.585 & 0.000 & 0.001 & 0.000 & 1.000 & 0.039 & 0.974 & 0.000 & 0.520 & 0.000 & 0.000 & 0.000 & 0.997 & 0.013 & 0.930 \\
\hline ISNand $\Delta \mathrm{ISN}_{\text {Germany }}$ & 0.000 & 0.000 & 0.000 & 0.000 & 0.013 & 0.000 & 0.011 & 0.000 & 0.000 & 0.000 & 0.000 & 0.000 & 0.032 & 0.000 & 0.045 & 0.003 \\
\hline ISRCand $\Delta I S R C_{\text {Gemany }}$ & 0.000 & 0.000 & 0.000 & 0.046 & 0.000 & 0.000 & 0.000 & 0.000 & 0.000 & 0.000 & 0.000 & 0.047 & 0.000 & 0.000 & 0.000 & 0.000 \\
\hline ISRV and $\Delta I S R V_{\text {Gemany }}$ & 0.000 & 0.000 & 0.000 & 0.000 & 0.000 & 0.000 & 0.000 & 0.000 & 0.000 & 0.000 & 0.000 & 0.000 & 0.000 & 0.000 & 0.000 & 0.000 \\
\hline$I Y N$ and $\Delta I Y N_{G e r m a n y}$ & 0.968 & 0.951 & 0.987 & 0.700 & 0.000 & 0.000 & 0.000 & 0.000 & 0.962 & 0.858 & 0.976 & 0.795 & 0.000 & 0.000 & 0.000 & 0.000 \\
\hline ILN and $\Delta \mathrm{ILN}$ us & 0.992 & 1.000 & 0.104 & 0.963 & 0.073 & 1.000 & 0.148 & 0.967 & 1.000 & 1.000 & 0.413 & 0.972 & 0.139 & 1.000 & 0.276 & 0.969 \\
\hline ILRC and $\Delta$ ILRCus & 0.937 & 1.000 & 0.999 & 0.947 & 0.000 & 0.019 & 0.000 & 0.000 & 0.957 & 1.000 & 0.998 & 0.932 & 0.000 & 0.008 & 0.000 & 0.000 \\
\hline ILRV and $\Delta$ ILRVus & 0.000 & 0.730 & 0.000 & 0.198 & 0.000 & 0.643 & 0.000 & 0.001 & 0.000 & 0.963 & 0.000 & 0.185 & 0.000 & 0.359 & 0.000 & 0.001 \\
\hline ISNand $\Delta$ ISNus & 0.000 & 0.000 & 0.000 & 0.000 & 0.000 & 0.028 & 0.000 & 0.036 & 0.000 & 0.000 & 0.000 & 0.000 & 0.000 & 0.055 & 0.000 & 0.058 \\
\hline ISRCand $\Delta$ ISRCus & 0.000 & 0.000 & 0.000 & 0.000 & 0.000 & 0.000 & 0.000 & 0.000 & 0.000 & 0.000 & 0.000 & 0.000 & 0.000 & 0.000 & 0.000 & 0.000 \\
\hline ISRVand $\Delta$ ISRV US $_{\text {S }}$ & 0.000 & 0.000 & 0.000 & 0.001 & 0.000 & 0.000 & 0.000 & 0.000 & 0.000 & 0.000 & 0.000 & 0.001 & 0.000 & 0.000 & 0.000 & 0.000 \\
\hline IYN and $\Delta$ IYNus & 0.605 & 0.999 & 0.000 & 0.132 & 0.000 & 0.000 & 0.000 & 0.000 & 0.853 & 0.999 & 0.170 & 0.699 & 0.0 & 0.000 & 0.000 & 0.000 \\
\hline
\end{tabular}

(1) This sample of 35 developed countries include all current 28 EU member states and also Iceland, Turkey, Norway, Switzerland, US, Japan and Canada.

(2) $\quad$ ILN = Nominal long-term interest rates; ILRC = Real long-term interest rates, deflator private consumption; ILRV = Real longterm interest rates, deflator GDP;

ISN = Nominal short-term interest rates; ISRC $=$ Real short-term interest rates, deflator private consumption; ISRV $=$ Real shortterm interest rates, deflator GDP;

IYN $=$ Yield curve $(=$ ILN - ISN $)$. 